Némethy, Judith Kesserü. "Exiled Hungarians in Argentina 1948-1968: The Formation of a Community.” AHEA: E-journal of the American Hungarian Educators Association, Volume 5 (2012): http://ahea.net/e-journal/volume-52012

\title{
Exiled Hungarians in Argentina 1948-1968: The Formation of a Community
}

\section{Judith Kesserủ Némethy, New York University}

Abstract: This paper presents the cultural activism of a group of Hungarian émigrés who fled their homeland following Soviet occupation at the end of World War II and arrived in Argentina around 1948. It deals with the intellectual activity of these exiles, especially through their cultural and educational institutions. Within five years of their arrival as dispossessed "D.P. 's, " they founded a Hungarian Center ("Centro Húngaro") that housed, among others, a theater group, a free university, a cultural and scientific academy, a weekend school, and scout troops. At the same time, new periodicals appeared, and a substantive number of books banned in Hungary were published. I argue that it is due to the work of these institutions that the community flourished and is vital to date, in spite of its isolation and lack of reinforcement through new emigrant waves, and in spite of its hostile relationship with the government of the People's Republic of Hungary and of a series of Argentine economic crises that forced many of its members to re-emigrate. I also discuss the impact the exiles had on their descendants, contending that as a result of the strong cultural foundations laid by them during their first twenty years of emigration, third-and fourth-generation Hungarian-Argentines have maintained to this day a strong cultural and ethnic identity, while fully integrating into Argentine society at large.

Keywords: Hungarian exiles, Hungarian diaspora, Cultural history, Twentieth century migrations, Argentine immigration, Cultural identity, Ethnic identity, Dual identity

Biography: Judith Kesserü Némethy is Clinical Professor in the Department of Spanish and Portuguese of New York University. She holds a Ph.D. in History (Hispanic Studies) from the University of Szeged. At NYU, she has taught courses in Spanish language, Latin American literature, and Spanish dialectology. Related to Hungarian studies, she has designed and taught Hungarian language courses at Cornell University, as well as History of the Hungarian emigration to Latin America at the University of Szeged. Her research interests are in Hungarian diaspora studies, Hungarian language, bilingualism, education, teaching methodology. She has published "Szabadságom lett a börtönöm" - Az argentínai magyar emigráció története19481968 ["My Freedom Became My Prison": A History of Argentinian-Hungarian Emigration, 1948-1968] (2003), and several articles on the above mentioned areas. She is past president of AHEA and administrator of scholarship applications to the Balassi Institute's Hungarian Language and Cultural Studies program for students of Hungarian descent. She is member of the Executive Committee of the Hungarian Scout Association in Exteris.

Succeeding waves of emigration constitute one of the many tragic features of twentiethcentury Hungarian history. Extreme poverty launched the first wave of emigration to the United States and South America at the turn of the century. World War I and the subsequent Treaty of Trianon rendered homeless hundreds of thousands of people, who in desperation sought shelter overseas. This was followed, until the early forties, by the emigration of communists, left-wing 
Némethy, Judith Kesserü. "Exiled Hungarians in Argentina 1948-1968: The Formation of a Community.” AHEA: E-journal of the American Hungarian Educators Association, Volume 5 (2012): http://ahea.net/e-journal/volume-52012

Jewish-Hungarians and others from lands that had been ceded to Romania, Czechoslovakia and Yugoslavia. By the end of World War II, millions of Eastern and Central Europeans fled in fear of the Soviet invasion. Emigrants spent the following years in a Europe devastated by war, in temporary camps, with little food and no future, looking with hope for countries that would accept them and where they could live in peace.

Between 1947 and 1949, a large group of Hungarians arrived in Argentina. With them and through the intense cultural activity they undertook, an effervescent intellectual life was born in the adopted land, the effects of which are still apparent today. In the case of any migratory group, the natural process of assimilation accelerates after the second generation: following an initial period of adjustment, it is normal for immigrant communities to incorporate themselves into their adopted society, an act that generally involves the loss of the native language and, frequently, even the loss of ethnic identity. Gradual integration, therefore, is inevitable, and Hungarians have not been an exception to this rule. However, this generalization is only partially valid in Argentina, where a distinctive and active Hungarian community still exists, albeit far less numerous than before. Assimilation there has seemingly delayed in some respects, although no new immigrants arrived after the Hungarian Revolution of 1956 and the community subsists entirely by force of reproduction. This phenomenon presents a clear contrast with the development of Hungarian communities in other immigrant countries, for example Canada, the United States or Australia. In Argentina - as evidenced by the latest issues of the Argentinai Magyar Hírlap - Hungarian language instruction, scouting, congregational and social life, the Hungarian press, a library, vocational theater and folkloric dance groups still flourish, exerting a decisive effect on the life of a Hungarian community of around 300 participating families. Moreover, these activities, performed and carried out in the native tongue, are overseen by Argentine-born Hungarians, most of them grandchildren of the original immigrants.

How can we explain the persistence of such distinct features of the Hungarian community in Argentina, and the vitality of its institutions and cultural activities? To what do we owe the subsistence, even if partial, of this strong ethnic identity, of this community life? The Hungarian immigrants in Argentina, along with those in Australia and New Zealand, belong to the Hungarian Diaspora farthest removed from Hungary. The community that was formed remained isolated from the homeland for decades. In addition, and in contrast to the other two countries mentioned, Argentina was a nation characterized by continual political and economic crisis that spanned a period of 50 years, which, together with its chronic inflation, produced a state of instability that brought with it an existential uncertainty. These factors decidedly influenced the lives of Hungarian residents. But at the same time, there was something more that was ingrained in the young offspring of Hungarian immigrants, something that instilled in them a strong idealism and a deep connection to their native roots, as well as a sense of duty to transmit their cultural heritage. The following section explores how this community was formed.

Hungarian exiles began arriving in Argentina toward the end of 1947. For the most part, they were fleeing the communist system being imposed in their homeland at the end of World War II. These immigrants were mostly members of the military, bureaucrats, university professors, physicians, artists, scientists, gendarmes, diplomats, engineers, writers, and jurists. They were mainly members of the middle class, although there were also aristocrats and industrialists among them. Most of them were exiled from Hungary at the end of 1944 or at the beginning of 1945, fleeing the advance of Soviet troops, but were joined later by another group, which emigrated between 1947 and 1949, consisting of people who had participated in the first 
Némethy, Judith Kesserü. "Exiled Hungarians in Argentina 1948-1968: The Formation of a Community." AHEA: E-journal of the American Hungarian Educators Association, Volume 5 (2012): http://ahea.net/e-journal/volume-52012

postwar attempts at democracy in Hungary. The two waves did not initially form a totally homogeneous unity: minor ideological differences could be found among the members, that today would be considered mere nuances. However, they did possess a common denominator their intense anti-Bolshevik conviction. (Borbándi 1989: 110-124) I will call these two groups of emigrants, who arrived in Argentina from the end of 1947 until 1949, the "exiled of 1948."

Why did these postwar Hungarian exiles choose Argentina? On the one hand, they knew they could not return to their native land in the near future. On the other hand, given the chaotic situation in Central Europe, those who had initially emigrated from that region could no longer count on living there in a dignified manner. Most of these exiles had been vegetating in dire conditions for years in Austrian and Bavarian refugee camps. Furthermore, they feared that at any moment there could be a new Soviet advance on Europe, a completely plausible idea at that time. For that reason, they focused their hopeful gaze on faraway places, preferably across the ocean. The possibilities, however, were limited. The most sought-after destinations (the United States, for example) had restrictive immigration quotas and many onerous requirements, above all for those coming from countries that had been designated "former enemies." France, England, Sweden and Belgium only accepted industrial and farm laborers or miners. Overseas, Canada, South Africa and Australia were looking for specialized workers, granting permits to settle only in isolated and uninhabited areas. In addition, Australia imposed a forced assimilation policy, especially regarding language use.

At the same time as strict immigration policies were in effect in so many places, the countries of South America, with Argentina, Brazil and Venezuela at the forefront, accepted "D.P.s" - displaced persons in the aftermath of the Second World War - with almost no preconditions. Argentina, in fact, offered the most advantageous opportunities, together with a favorable climate and a standard of living and economic development comparable to Canada and Australia. ${ }^{1}$ With a renewed systematic plan to populate its territory, Argentina set its sights high on European immigration, primarily on Spaniards and Italians. The objective was to develop the Argentine economy through newcomers who could contribute socially and economically to society. In 1946, the government of President Juan Perón published the First Five Year Plan, which authorized an annual immigration of 50,000 persons, giving priority to farmers, fishermen, technicians, and specialized workers. But the denizens of the enormous Central European refugee camps (numbering over 2 million) represented yet another valuable source or manpower for the country and, after 1947, were given permission to seek entry. Within these camps, together with the workers, intellectuals were added to the list of acceptable - even desirable immigrants. (Andera, 1955: 106-112). Consequently, Hungarians in the D.P. camps were then eligible to enter Argentina along with the other refugees. We have only approximate data concerning Hungarian immigration to Argentina, with huge discrepancies, between 3,000 to 14,000 Hungarians. ${ }^{2}$ The reason for this vagueness can be explained - among others - with the

\footnotetext{
${ }^{1}$ At the end of World War II, about 2,000,000 people (250,000 Hungarians) left their homes in Central and Eastern European countries and became "Displaced Persons" (D.P.'s). Between the end of 1947 and October 1948, the International Refugee Organization (IRO) was able to accommodate over 200,000 refugees. [DM, 10.12.1948] ${ }^{2}$ Under 3000 according to official data of the Argentine Immigration Office obtained by László Kurucz (1999); 14,000 according to the statistics of Zsuzsa Csikós (1988/7); 12,000 according to the 1954 Centro Húngaro survey. In addition: according to official data of the International Refugee Organization (IRO), in 19484800 Hungarians came to Argentina from the German and Austrian sectors under North American control (at the same time 1700
} 
Némethy, Judith Kesserü. "Exiled Hungarians in Argentina 1948-1968: The Formation of a Community.” AHEA: E-journal of the American Hungarian Educators Association, Volume 5 (2012): http://ahea.net/e-journal/volume-52012

Treaty of Trianon of 1920, when two-thirds of Hungary was distributed among its neighbors. With it, a large number of ethnic Hungarians (one third of all Hungarians, to be exact) became de facto citizens of Romania, Slovakia, Yugoslavia and Austria and obtained documentation from these countries. Thus, after World War II they entered through quotas granted to Romanians, Czechoslovakians or Yugoslavs. Moreover, in many cases, they lacked personal papers.

The immigrants, after a three week maritime voyage, received food and lodging for a duration of one to three weeks in the so-called "Immigrant Hotel," which was located in the vicinity of the port of Buenos Aires. Given Argentina's economic prosperity in the late 1940s, almost everyone found work and was able to rent a place to live right away. A large sector of the established community of Hungarian residents offered the recently arrived invaluable help in this endeavor, officiating as interpreters, giving useful advice and making available personal contacts, in many cases lending money, or donating furniture and household goods. This aid was often extended to rent payments. It was in this way that the majority of the new arrivals obtained living quarters in the capital and in the northern and southern suburbs ("Greater Buenos Aires"). It was not uncommon for several families to share a two-bedroom apartment.

Jobs were plentiful, but not in the intellectual field, and so diplomats and lawyers became truck drivers, factory and shop workers, hotel porters, laundry employees, and other workingclass employees. They even went so far as to try their luck in new enterprises without knowing the local situation, without specific research, and without speaking the language: the former minister took up brokerage, the journalist painted wooden toys, the actor taped lampshades, and the university professor learned carpentry.

The life of the new immigrants was originally organized around religious congregations and in a few of the social clubs of the "old" immigrants - those who had emigrated in the early twentieth century. While Catholics joined "old immigrants" at mass in the Catholic Mission in downtown Buenos Aires, new immigrants organized their own joint Protestant congregation, with Sunday services in the Anglican church in the Palermo section of Buenos Aires. By 1954 the congregation had over 400 members.

Community life for the new immigrants was more complex than finding entry-level jobs. In accordance with the different emigrant waves, the existing clubs were separated by geography, ideology, social background, and politics. There was a wide range of associations, from apolitical to those espousing a far-left ideology. Enormous distances separated associations between the Southern and Northern districts of the Capital and Gran Buenos Aires. In the city itself was the apolitical Hungarian Charitable Organization. To the North, in San Isidro, were the BAME (Buenos Airesi Magyar Egyesület, a right-leaning Christian organization) and the Hungarian Cultural Society of Olivos (apolitical). About 40 miles or more from these and about 10-15 miles from each other, in the Southern districts were the Hungarian Clubs of Avellaneda, of Dock Sud, of Wilde, and the Choral Group of Valentín Alsina (all four Christian workingclass $)^{3}$. All these clubs were formed by emigrants arrived from regions detached from Hungary by the Treaty of Trianon. ${ }^{4}$ There were two far-left leaning clubs, the Törekvés Sport Club $^{5}$ and

went to Australia, 2100 to Brazil, 210 to South Africa, 130 to the United States, and 380 to Canada) ( Kesserü, 1984).

${ }^{3}$ Valentin Alsinai Magyar Dalkör is the only institution established in Gran Buenos Aires before 1948 still active today.

${ }^{4}$ There were arguably also Jewish Hungarians among these immigrants, but no precise data were found.

5 Dissolved in the 1960's 
Némethy, Judith Kesserü. "Exiled Hungarians in Argentina 1948-1968: The Formation of a Community.” AHEA: E-journal of the American Hungarian Educators Association, Volume 5 (2012): http://ahea.net/e-journal/volume-52012

the Association of Hungarian-Speaking Jews in Argentina (AMZSE-Argentínai Magyarajkú Zsidó Egyesület), founded in 1938 through the fusion of three Jewish clubs. ${ }^{6}$ This last organization maintained a certain level of exclusivity from the other clubs of the Hungarian community (although it regularly placed announcements of its activities in the Hungarian periodicals). The connection among these ideologically vastly different clubs was neutral, with little or no interaction between them during the interwar years. However, the relationship between the Jewish community and the rest of the Hungarians began to cool at the end of World War II.

While the majority of the "old" immigrants received the newcomers with good will and helped them in their first endeavors in finding housing and jobs, the far left was relentless in its attacks against them. These started with the Hungarian diplomatic representation in Buenos Aires, which already in 1948 had begun its campaign against the new immigrants directly or through the Törekvés Club. Then the AMZSE joined in the onslaught through articles published in their periodical Hatikva, initiating a resonant and nefarious attack. All of those who emigrated in 1945 were called "fascists" without any differentiation, despite the fact that, though there had been "fascists" or "arrow crosses" among them, these represented only a small fraction of the immigrants who arrived in Argentina in 1948. ${ }^{7}$

Irrespective of the alignments among the "old immigrants," most of the Exiles of '48 did not participate in the existing associations. Although the faraway motherland united all of them, their respective backgrounds and circumstances differed radically. It was for this reason that, once their basic needs of housing and work were met, the Exiles of 48 began to get together in greater numbers and with increasing frequency in order to find a solution to their intellectual and educational wants. Among the tasks at hand were the acquisition of Spanish language and technical skills, and also, crucially, the continuation of Hungarian language and cultural education.

One prominent member of the 48-ers, Márton Kerecsendi Kiss, elevated the intellectual mission of the exiled community to new moral heights. Typical of his intellectual commitment is the following quote, where he outlined with precision the duties of the Hungarian refugees:

The moral measure of a society is its intellectual life. Our émigré society is forming itself right now. We cannot view its development with indifference. What will become of it? Will it fulfill the mission it is bound to by the dictates of the millennium strong Christian tradition of our nation's creative culture? Will we, as émigrés, be capable of recognizing the limitless possibilities of our intellectual component? We do not know the answer to this yet. But let us engrave it well on our memory: Each and every one of us is responsible for this answer.

[Egy társadalom erkölcsi értékmérője: annak szellemi élete. A mi emigrációnk társadalma most van kialakulóban. Nem nézhetjük közömbösen fejlödését. Mi lesz belöle? Teljesíti-e azt a feladatot, amire egy keresztény kultúrában élö, alkotó, ezeresztendös nép

\footnotetext{
${ }^{6}$ AMZSE as social club functioned until 2006. In 1966 it acquired a sports facility in Tigre, which still functions today. (Club AMZSE Deportivo y Náutico. Sociedad Israelita de Habla Húngara en la Argentina http://www.amzse.org.ar/) Today it has only one Hungarian speaking member, Judit Fodor.

${ }^{7}$ In Hungary, for 45 years, it was customary to apply this collective epithet to the huge mass of people who fled around 1945, although the majority of the population did not understand clearly the real meaning of the term nor its historical antecedents.
} 
Némethy, Judith Kesserü. "Exiled Hungarians in Argentina 1948-1968: The Formation of a Community." AHEA: E-journal of the American Hungarian Educators Association, Volume 5 (2012): http://ahea.net/e-journal/volume-52012
hagyományai kötelezik? Meglátja-e a lábrakelt ország szellemi arcának kiteljesedéséhez a határtalan lehetöséget? E kérdésekre még nem tudunk feleletet adni. De véssük fel jól emlékezetünkbe, hogy ezért a feleletért mindnyájan együtt és egyenként felelösek vagyunk]. (Kerecsendi Kiss, 1949)

In his lecture at a conference in June 1949 Kerecsendi delineated a plan for the following years and singled out five vital areas - not including existing institutions, such as the press or theater for the cultural survival of the community: a conference center, a free university, a HungarianArgentine organization, a weekend Hungarian school, and, finally, the printing and safe-keeping of books. Two years later, all five institutions proposed in his visionary speech had been realized. Below I outline the activities of seven immigrant institutions established by the Hungarian community in Argentina.

\section{The Centro Húngaro}

The fulcrum of Hungarian cultural life in Argentina is closely linked to the establishment of the Hungarian center, the Centro Húngaro. It is here that the creative force that turned into the intellectual motor of the community was concentrated. With few exceptions, all those who constituted and directed its institutions were found at the Centro. Throughout the years, it was the seat of the Mindszenty Scientific and Cultural Academy, the Péter Pázmány Free University, as well as of periodicals and publishers. It also housed the theater group Délamerikai Magyar Színjátszó Társaság (South American Hungarian Theatre Company), the Community of Former Hungarian Combatants (M.H.B.K.), artillery men and aviators, the Circle of Engineers and Technicians, a library, and, above all, the youth groups: the weekend school (Zrínyi Ifjusági Kör) and the Scout troops. In addition, the lay leadership of the church denominations came from its ranks. From the sixties it also housed the Szabad Fórum (Free Forum), which dealt with topics in Hungarian history, with the political past and present, and with vital questions of the Hungarian nation. Many determined "intellectual day laborers," anonymous for the most part, forged such a stronghold, that even today, sixty years later, it is the center of the cultural life of Argentine Hungarians. (Vácz ms.) ${ }^{8}$

Within the Centro Húngaro, the Mindszenty Scientific and Cultural Academy was the first one established. Among its main objectives were the preservation and diffusion of Hungarian culture, the development of Hungarian-Argentine links and the dissemination of facts about Hungary's subjection by the communist dictatorship, such as the mass deportation of upper and middle-class families. In order to fulfill these objectives, a series of conferences and publications was designed. The Academy was divided into three departments: human sciences, natural sciences, and the department of economics, literature, and art. The activities and

\footnotetext{
${ }^{8}$ Independently from the Centro Húngaro, I should mention the pioneering work of Dr. Géza Girsik and of his wife Piroska ("Piri néni"), in the field of education. In 1949 they were the first to bring together children from the community in order to teach them Hungarian. They directed the Hungarian School for many years at the Olivos Hungarian Cultural Association. They even organized a summer home for Hungarian children, taking advantage of free programs of the Eva Perón Foundation. Thus, in 1950, a whole group of 1948 immigrant Hungarian children enjoyed the summer installations of the vacation colony "General Pistarini," near Ezeiza (in Western Gran Buenos Aires), free of charge. (The Girsik couple had already begun their educational activity among the Hungarian refugee children in 1945, at Innsbruck, Austria).
} 
Némethy, Judith Kesserü. "Exiled Hungarians in Argentina 1948-1968: The Formation of a Community.” AHEA: E-journal of the American Hungarian Educators Association, Volume 5 (2012): http://ahea.net/e-journal/volume-52012

influence of the Academy extended throughout the whole of Hungarian emigration. Also included in its program were contacts with representatives of Argentine intellectual life, as well as a close collaboration with scientists and artists of other nationalities. It should be noted here that Hungarian immigrant youth demanded cultural activity and made every effort to organize itself with this in mind. Adolescents who had fled Hungary with their parents between the ages of 10 and 15 managed to complete their high school studies in the refugee camps of Germany. After they arrived in Argentina, economic realities prevented them from continuing their education: they had to work to assure their families' livelihood. In November of 1949, the following article was published in Magyarok Útja (1949) under the title "A buenosairesi húszévesek gondja" ["The Worries of Twenty-Somethings in Argentina"]: "...There are approximately 80 to 100 of us, young people brought to this happy land of liberty through the adverse destiny of the refugee. We are not able to study, we must fight for our daily bread...In no other place on earth are there so many Hungarian scientists, professors, teachers, and educators as here in Argentina. The difficulties are well known. However, we beg everyone concerned, the organizers of the future Mindszenty Academy, the directors of the Centro Húngaro: try to create possibilities so that we can study." [“... 80-100-an lehetünk, akiket a mostoha menekült-sors ide, a szabadságnak erre a boldog földjére vetett. Nem tanulhatunk a kenyérharc miatt... Sehol a világon nincs ma egy csomóban annyi tudós, professzor, tanár, nevelö, mint itt Argentínában. Ismeretesek a nehézségek. Mégis kérünk mindenkit, akiket illet, a leendö Mindszenty Akadémia szerveit, a Centro Húngaro vezetöségét: teremtsenek lehetöséget a mi tanulásunkra."]

Thus was born the Péter Pázmány Free University. Courses were offered on a trimester basis during which 4 hours of classes a week were given, with students formally matriculated. The first trimester, held in 1952, had 75 registered students, the youngest 14 and the oldest 68 years old. Thirteen subjects were taught along with a series of lectures that were held throughout one or two trimesters. Its activities were reported regularly in the Délamerikai Magyarság (Hungarians of South America), a periodical that dedicated a permanent section to the Free University.(DM 1952/8/1,1952/11/18). The running of the Free University echoed throughout the Hungarian press in the free world. The Hungária in Munich, Dél Keresztje (Southern Cross) in Australia, Új Magyar Út (New Hungarian Path) in Washington, Amerikai Magyar Népszava (The Voice of the Hungarian People in America) in New York, and Ahogy Lehet (However You Can) in Paris, all published articles recognizing its work. Radio Free Europe of Munich, in its edition for Hungary, transmitted a ten-minute long broadcast about the establishment of the Free University. It pointed out the sharp contrast between the willingness of the Buenos Aires organizers to do voluntary work for the benefit of their cause and the obligation imposed on people by the Communist Party in Hungary to do "voluntary work" in order to exceed the standard production. During the first year, congratulatory notes arrived from exiled personalities all over the world: Ottó von Habsburg, Miklós Horthy, Tibor Eckhardt, Ferenc Kisbarnaki Farkas, András Domahidy, Lipót Edelsheim-Gyulay, László Acsay, János Lotz, Miklós Kállay, Béla Szász, Béla Kolossváry, to name just a few. The hope was expressed that "the Free University would be the starting point to the mutual encounter of all valuable Hungarian elements." The University inspired a Hungarian Studies Seminar in Montevideo, and offered an exchange of study programs and lecturers. (DM 1952/11/21) 
Némethy, Judith Kesserü. "Exiled Hungarians in Argentina 1948-1968: The Formation of a Community.” AHEA: E-journal of the American Hungarian Educators Association, Volume 5 (2012): http://ahea.net/e-journal/volume-52012

The Free University's activity was also closely watched by the Hungarian Foreign Ministry, irked by the discovery that it had the full support of the Western diplomatic corps in Argentina. In fact, the British Embassy in Buenos Aires collected donations for the Free University, including books donated by the University of the Netherlands through the Dutch embassy. This was confirmed by the Hungarian Embassy, which also added that quite a few members of Western embassies had expressed their admiration for the Hungarian Free University's achievement. (MOL 1952). Among the members and presenters of the Academy and the Free University, special mention should be given to Mihály Ferdinandy, Lajos Szalay, László Dobosi Szabó, Ernő Dohnányi, Antal Páger, Magda Zalán, Szabolcs Vajay, to name only a few.

The Centro Húngaro also sought contacts with other societies that had similar objectives in the local sphere and in the world. From 1952 onward, through the Council of Associations, the Center maintained communication on a regular basis with other members of this organization. These included the Sociedad Húngara de Dock Sud, The Asociación Cultural Húngara de Olivos (Hungarian Cultural Association of Olivos), BAME (Buenos Airesi Magyar Egyesület: Hungarian Association of Buenos Aires), Coro Húngaro de Valentín Alsina (Hungarian Choir of Valentín Alsina). Together they organized numerous events: choirs, performances, dinners, balls, and the celebration of Hungarian national holidays. With the establishment of the Hungarian Center of Córdoba (by members of the 1948 generation), the first sister association appeared within the interior of the country. It was a unique enterprise, since in fact several groups or associations of Hungarians already existed in the different provinces of the vast Argentine territory, with which the 48-ers had little or no contact. They consisted of immigrants arrived in the late twenties and thirties to work the fields and to build the railroads: in Santa Fe, Misiones, Comodoro Rivadavia (in Patagonia), Rosario, Tucumán, Salta, and Chaco. ${ }^{9}$

Excellent contacts with numerous personalities from Argentine society were soon established by the Centro Húngaro. The Argentin-Magyar Társaság (Argentine-Hungarian Society), with different associates of the Centro Húngaro among its members, was also created. It was an organization of mutual aid and charity, and in addition sponsored many successful exhibits, such as the Hungarian Industrial Exposition, with the participation of celebrities from Argentine public life.

The year 1956 brought with it a fullness of activity to the community, with the Centro Húngaro squarely in the limelight. It all began with the festivities of the "Quincentenario de las Campanadas del Mediodía" (The Noon Bell Quincentenary), which commemorated the 500 year anniversary of the 1456 Hungarian victory over Turkish troops, effectively preventing the expansion of the Ottoman Empire into Europe. The crowning act was the "Exposición aniversario," (Anniversary Exhibit) that was shown for ten days under the slogan "In Defense of the West." The productions had two objectives, the first to show both citizens and non-nationals residing in Argentina the importance of this historical event in terms of its military value and its moral and cultural significance. Secondly and on another level, it attempted to trace a parallel between the Turkish invasions into Hungary and the three more recent invasions of the Russians:

\footnotetext{
${ }^{9}$ Today, there are active Hungarian communities in Bariloche, Córdoba, and Santa $\mathrm{Fe}$, as well as the two colonies in Chaco. These last ones, established in 1929 by "Trianon migrants" from Transylvania, are the Colony of Villa Angela and Coronel Du Graty (originally Nandubay), both in Chaco, near the border with Paraguay. (Haynalné Kesserü, 2007)
} 
Némethy, Judith Kesserü. "Exiled Hungarians in Argentina 1948-1968: The Formation of a Community." AHEA: E-journal of the American Hungarian Educators Association, Volume 5 (2012): http://ahea.net/e-journal/volume-52012

in 1849 and between 1914-16 and 1942-45. (MHÉ 1956/7). Both events organized by the Centro helped awaken the interest in the Hungarian past and present among the Argentine population. Therefore, when the Hungarian Revolution of 1956 broke out, the community - both Hungarian and Argentine - immediately responded: the nucleus of the main activities of the Centro Húngaro supported this epic deed with processions, demonstrations, the sending of medical supplies, food, and clothing to the fighters, reception of new exiles, exhibitions, and other enterprises to inform the world about the facts of the revolution for at least the next five years. (NKJ 2010)

The chain of events surrounding the Hungarian revolution and its swift crushing by the Soviet forces, which coincided with a series of crippling economic crises that plagued Argentina. had a double repercussion on the Hungarian community. First, few '56 exiles came to Argentina, preferring countries that offered them better economic opportunities. Of those '56-ers who did come, most continued their migration within the next few years to the United States. Moreover, a number of Hungarians from previous emigrations also relocated to other countries, mainly to the United States and Canada, but also to Western Europe. I should mention some of the most famous scientists, artists and writers who left during this decade: Mihály Ferdinandy, Lajos Szalay, Zita Szeleczky, Piroska Vaszary, Lajos Cselle, and Szabolcs Vajay. Over 50 of the émigrés who left Argentina during this period had actively participated in the life of the community. Among them were István Vörösváry and Márton Kerecsendi Kiss, publisher and editor of Magyarok Útja; their departure meant the end of this important publication. ${ }^{10}$ Finally, this decade also brought the return to Hungary, in August 1956, of the famous actor Antal Páger, lured back to his homeland by the (false) promises of the Embassy of the People's Republic of Hungary. Páger's return resulted in a cause célèbre bordering on scandal among Hungarians both in Hungary and in Argentina, as I shall discuss in more detail, below. (NKJ 2003)

Despite these substantial losses of important personalities through their reemigration to other countries, the Centro Húngaro reached its apex in the late 50's and in the next decade membership increased to over 400 participants, which included a handful of '56-ers). Events organized by groups under the auspices of the Centro promoted a very active social and cultural life: conferences and symposia promoted by the Mindszenty Academy, Scout gatherings, and Christmas festivities, among others, convened hundreds of people, sometimes even thousands. ${ }^{11}$ From the mid-sixties on, the Centro was also home to the Free Forum, a group of liberal- leaning

\footnotetext{
${ }^{10}$ Report of the Mindszenty Academy activity in 1959. (Vácz ms.)

11 (Magyar Népköztársaság követsége: "A magyar emigráció helyzete. A Centro Húngaro meglehetösen ügyes taktikát alkalmazva, különbözö kulturális rendezvényekkel igyekszik hatni a jobboldaltól való eltávolodás gondolatával foglalkozó emigrációra. Ilyen megnyilvánulás volt a napokban a Centro Húngaro székházában megrendezett magyar-argentin bélyegkiállítás. A kiállítás megrendezésén különösebb, ellenünk uszitó megnyilvánulásra nem került sor. [...] A kiállítás müvészi érték szempontjából gyenge, technikailag viszont jól volt szervezve. [...] A mellékelt kiállítási levelezölapon látható Dugovits Titusz reprodukció használata miatt véleményem szerint eljárást lehetne indítani a kiadó szerv ellen." [The Embassy of the Popular Republic of Hungary: "Situation of the Hungarian colony. The Centro Húngaro, following fairly capable tactics, utilizes diverse cultural acts to try and influence immigrants playing with the idea of distancing themselves from the right. One of these actions was the Hungarian-Argentine postal stamp exposition in the Centro Húngaro. There were no special protests against us at the exposition. [...]-The exposition was of poor artistic quality but technically it was well organized. [...] In my opinion, we could initiate a procedure against the editor of the enclosed stamp that was distributed at the exposition for its unauthorized use of the reproduction of Titusz Dugovits." [MOL 1959.10.28].
} 
Némethy, Judith Kesserü. "Exiled Hungarians in Argentina 1948-1968: The Formation of a Community.” AHEA: E-journal of the American Hungarian Educators Association, Volume 5 (2012): http://ahea.net/e-journal/volume-52012

exiles affiliated with the Délamerikai Magyarság who held bi-weekly meetings with invited lecturers on topics related to Hungarian history and politics.

Eventually the Centro Húngaro fell victim to city planning when in 1971 its building on Cerrito street was demolished by the city government with the aim to extend the imposing Avenida 9 de Julio, and the Centro was left without a meeting place. Given that most members lived (and still do) in the northern zone of the Gran Buenos Aires, the Centro's leadership started discussions with the other two associations of that area, the BAME and the Hungarian Cultural Association of Olivos. In 1973, these institutions merged into the new "Hungária, Asociación Húngara en la Argentina," still the center of Hungarian community life today. It is located on the land of the old Hungarian Cultural Society of Olivos, whose premises have been modernized and enlarged into an elegant two-storied building.

\section{Educational and Social Institutions}

An outstanding example of the intellectual commitment of the émigré community in Argentina was the flourishing of its institutions dedicated to youth education. Their cultural achievements were due at first to the work of a small group of Hungarian nuns that belonged to the Order of Maria Ward. Through tenacity and a deep faith, they enjoined the exiles to gather funds in order to buy property in Plátanos, a district in the extreme south of Greater Buenos Aires, where they founded a school. The students were given classes both in Hungarian and, as mandated by the government, also in Spanish. This institution transformed itself into the intellectual center of the youth, not only in schooling but also in scouting. Apart from its school in Plátanos, it initiated the weekend program at the Centro Húngaro, with two levels of instruction. At the same time, scout troops were formed in four areas of the Gran Buenos Aires. By the mid fifties, their membership ran around 150 scouts.

Weekend schools and scout troops have been fundamental in maintaining Hungarian culture abroad. In Argentina the role of the weekend school was assumed by the Zrínyi Youth Circle established by Sister Mária Juhász. The scouts of Buenos Aires are members of the Hungarian Scout Association in Exteris, an organization of about 3500 scouts of Hungarian descent with headquarters in the United States and scout troops dispersed throughout four continents. In Argentina, the young people are integral to both the scout troops and the Zrínyi Youth Circle. These institutions have always worked in collaboration and are currently educating the third and fourth generation of Hungarian children outside of Hungary, in many cases the great-grandchildren of the founders of these same organizations. The scout docents and directors who are working today with these children proceed from their own rank and file, all of them having been born in Argentina. In both institutions the educational activity, with classes held every Saturday, begins with kindergarten and ends with high school.

Another prime ingredient of the cultural development of the community was the Hungarian Theater in Buenos Aires, whose magnificent productions ("parádés elóadásai") were lauded in the introduction to a book on the Hungarian past in Latin America published in Hungary (Szabó 1982). These plays were assembled of casts that could not have been seen even in Budapest, bringing together on one stage actors of prime category. The professional actors and actresses who emigrated to Argentina - Lajos Cselle, Olga Eszenyi, Miklós Hajmássy, Júlia Komár, Antal Páger, Zita Szeleczky, Piroska Vaszary and László Szilassy - as well as the playwright Márton Kerecsendi Kiss, established the first cultural and social activities of the Hungarian exiles in Argentina. They founded the Magyar Színjátszó Társaság (Hungarian 
Némethy, Judith Kesserü. "Exiled Hungarians in Argentina 1948-1968: The Formation of a Community." AHEA: E-journal of the American Hungarian Educators Association, Volume 5 (2012): http://ahea.net/e-journal/volume-52012

Theater Company) in 1948. Works by Kálmán Mikszáth, Zsigmond Móricz, László Németh, János Bókay, János Vaszary, Márton Kerecsendi Kiss, Lajos Marschalkó, Scribe, Druten, I. Halász, Ferenc Herczeg, W. Somerset Maugham, Nicodemi, Sándor Hunyadi, Viktor Rákosi, among others, were brought to the stage.

The Magyar Színjátszó Társaság had a difficult beginning due to the fierce attacks of the far-left. There was an offensive led by Hatikva to boycott it, because its members were rightwing anti-Bolshevik. Harassment of some of its members began, based on the assumption that they had participated in films considered pro-Nazi. Such was the case with Páger, Szeleczky, Szilassy and Kerecsendi Kiss. (In all cases time proved these claims to be unfounded). ${ }^{12}$

The Magyar Színjátszó Társaság's first production appeared in December of 1948 and eventually one new work was shown every month. In 1950, Szeleczky separated from the group and formed the Argentínai Magyar Nemzeti Színház (The Hungarian National Theater in Argentina), which dissolved in 1954. Their biggest productions were Madách's Az ember tragédiája (The Tragedy of Man) and Katona's Bánk Bán. ${ }^{13}$ In 1952, the qualifier "of South America" was added to the name of the Hungarian Theater Company (Délamerikai Magyar Színjátszó Társaság) because the group also gave performances in Montevideo, São Paulo, Rio de Janeiro, and Caracas. After its close in 1957, it was revived temporarily between 1959 and 1967 under the direction of Miklós Hajmássy. (Vácz ms.).

The various theatrical companies put on a total of 117 productions in Argentina, presenting 99 different works (18 plays were shown twice) written by 65 Hungarian playwrights and 34 non-Hungarian ones. Eleven professional and one hundred amateur actors performed the roles. The Hungarian Theater Company of South America offered a total of 103 plays, the Hungarian National Theater of Argentina 8, and the New Hungarian Theater 6. Hungarian theatrical art in Argentina represents a valuable component in the cultural life of the exiled nationals in South America.

\section{Book Publishing and the Press}

A pivotal element in the development of Hungarian cultural life was the role of the exiled publishers. In contrast with former emigrations, that of ' 48 could not count on literary shipments out of Hungary. War had destroyed many books and many more were forbidden through the political fanaticism that characterized Rákosi's dictatorship. Furthermore, it was practically impossible to get books that had been written prior to WWII. But publications in the native language were in high demand, which explains the important nature of the press and publishing houses, which printed and disseminated not only classical Hungarian works but also texts that were written by émigrés. That such a level of publishing activity was accomplished within a short period of time after settling in Argentina, without organized financial backing, represents a heroic effort on the part of those who dedicated themselves to this undertaking. In the 50's and

\footnotetext{
${ }^{12}$ Neither of these actors were members of any political party, although they were of right-wing conviction, and as such were used by the political machine. An example is Szeleczky's recording in 1942 of a Petőfi poem, „Föl $a$ szent háborúra," that was repeatedly broadcast in 1944 for war propaganda. She left Hungary in 1945. In 1946 an international order of arrest was issued against her, in 1947 a People's Court condemned her in absentia to three years in prison for war provocation. (Data from Szeleczky scholar Zsolt Péter on 6.2.2012). After spending 14 years in Argentina, Szeleczky moved to the United States in 1962, repatriated to Hungary in 1998, and died in 1999.

${ }^{13}$ Szeleczky performed in an Argentine film, "Vivir un instante", under the alias of Diana Toldy. She also had 6 solo performances of Hungarian poetry.
} 
Némethy, Judith Kesserü. "Exiled Hungarians in Argentina 1948-1968: The Formation of a Community.” AHEA: E-journal of the American Hungarian Educators Association, Volume 5 (2012): http://ahea.net/e-journal/volume-52012

60 's, seven publishers not only provided the entire community of immigrants with reading material but also shipped works abroad, especially to Brazil, to various cities in the United States, to England and even Australia. One measure of the success of this enterprise was the fact that a large number of books reached two and sometimes three printings. Between 1948 and 1968, 232 publications in Hungarian appeared in Argentina. The main disseminators of Hungarian works were the principal newspapers: Délamerikai Magyarság and Magyarok Útja, as well as the publisher firms Kárpát, Danubio, Pannonia, and Transsylvania.

Among the classics brought out by these publishers were works such as Imre Madách's The Tragedy of Man, József Katona's Bánk Bán, János Arany's Toldi trilogy and his Historical poems and ballads, Petőfi's complete poetry, Jókai's Erdély aranykora. They also published books by forbidden authors, like Pogányok and Pro Libertate by Ferenc Herczeg; Láthatatlan ember bz Géza Gárdonyi; Uz Bence, Íme az emberek, and A sibói bölény by József Nyírō; Tizenhárom almafa, Farkasverem, Az antikrisztus és a pásztorok and Devolvedme mis montañas (Adjátok vissza a hegyeimet - in Spanish) by Albert Wass; selections of poetry by Sándor Mécs and Sándor Reményik, as well as historical novels such as Harsányi's Mathias Rex, Makkai's Táltoskirály and Sárga vihar, and Rózsa Ignácz's Anyanyelve magyar. Of special interest today are the publication of Miklós Horthy's Memoirs (Emlékirataim), as well as Virgil Gheorghiu's $A$ huszonötödik óra (The $25^{\text {th }}$ hour).

A huge array of literary supplements, yearbooks, and literary journals was published from 1948 well into the sixties by Délamerikai Magyarság and Kárpát, in which works by Márai, Kosztolányi, Jókai, Krúdy, Margit Kaffka, Dezső Szabó, Zsigmond Móricz, Áron Tamási, Karinthy, Surányi, as well as poems by Ady, Babits, Kassák, Illyés, Gyula Juhász, Reményik, László Mécs, Lőrinc Szabó, Weöres, and Zelk, among others, appeared. These periodicals also included columns on émigré literature, film, and music, with works by or on János and Gábor Vaszary, Faludy, Ferenc Fáy, György Gömöri, Márton Kerecsendi Kiss, and Tibor Tollas. Essays on Argentine literature and literary history also appeared regularly.

Between 1948 and 1968, a total of 232 books in Hungarian were published in Argentina. Of these, $63 \%$ were printed by the publishing firms, $18 \%$ by Hungarian émigré institutions, $15 \%$ by individual 1948-ers, and 4\% by others (immigrants from before 1948, Embassy of the People's Republic of Hungary, Argentine publishers, and individuals). During the same period, 125 titles in Spanish on Hungarian topics appeared, 35\% of which were published by the Exiles of 1948. Hungarian book publishing in Argentina reflects changes in émigrés' literary tastes and interests. At the beginning of the 50's, most of what was published was classical literature and new works by émigré authors. From the mid-50's on, the emphasis switched to political and historical topics, in novels and essays. The books published in Spanish dealt mostly with contemporary Hungary, its political and historical background, as well as Hungarian cultural treasures.

As could be expected, the question of authorship rights would come up at some point from the Hungarian authorities. Many authors were still alive, others were classics whose printing rights in principle was the State's domain Yet from the documents of the National Archives we can deduct that the Embassy of the People's Republic of Hungary had little knowledge of the publishing work of the exiles. The first instance of some mention of illegal publishing came in 1959 regarding the publication of Albert Wass's Az Antikrisztus és a pásztorok and Virgil Gheorghiu's A huszonötödik óra. The Hungarian Office of Defense of Authors' Rights presented in 1960 a list of 17 titles published illegally in Argentina between 
Némethy, Judith Kesserü. "Exiled Hungarians in Argentina 1948-1968: The Formation of a Community.” AHEA: E-journal of the American Hungarian Educators Association, Volume 5 (2012): http://ahea.net/e-journal/volume-52012

1952 and 1957, but no action was taken at that time. When in 1964 the Buenos Aires Embassy summoned Dr. János Theész, publisher of Editorial Transylvania, regarding authorship rights of Irén Gulácsy's novel Fekete Völegények (Black Grooms), Dr. Theész energetically refused this claim, arguing that all the books he published were blacklisted in Hungary and their authors stripped of their rights. This episode illustrates clearly the differences in principles between the Hungarian authorities and the exiled publishers. (MOL 1965/10/20)

There existed two long-standing Hungarian periodicals in Argentina: Magyar Szó (Hungarian Word) and Délamerikai Magyarság (Hungarians of South America). Magyar Szó, founded in 1924, aimed at being the voice of Hungarian residents in Argentina. It was the foundation of Hungarian community life in Argentina. Until its demise in 1958 with the death of its only publisher, it was the voice of and bond between all Hungarian immigrants, helping newcomers and unemployed, organizing free medical attention for the poor.

The second newspaper, Délamerikai Magyarság, established in 1929 and continuing under different names and ownerships - until 2003, would play a decisive role among the new immigrants. The paper became the voice of the center-left leaning members of the generation of '48. ${ }^{14}$ The most striking of its initiatives was the integral role it played in the Hungarian Revolution of 1956, when it published two books in Spanish: Hungría no se rinde (Hungary Will Not Surrender) and El drama de Hungría (The Drama of Hungary), subtitled "The Hungarian Revolution: Radio Broadcasts in Chronological Order from the $23^{\text {rd }}$ of October to the $4^{\text {th }}$ of November, 1956." Also published in this book were the now famous illustrations of Lajos Szalay.

As a counterpoint to Délamerikai Magyarság among the generation of '48, the Magyarok Utja (first called Magyar Út), a "political, social, literary and artistic periodical of the antiBolshevik Hungarians in exile," ["a számüzetésben élö, antibolsevista magyarság politikai, társadalmi, irodalmi s müvészeti lapja."] was established in July 1948. Its orientation was Christian, center-right and independent, with no party ties past or present, aiming at editorial excellence in all areas. It became one of the most prestigious and professional, albeit short-lived, publications of the whole emigration of 1945. It succumbed to economic pressures in 195 . $^{15}$

Both Délamerikai Magyarság and Magyarok Útja were forcefully attacked by Hatikva, "the periodical of the Hungarian-Speaking Jews of South America," an international Zionist newspaper published since 1947 both in Argentina and in Israel and appearing irregularly until the 1970's. Hatikva initiated multiple campaigns against the émigrés of 1948, against their publications as well as against their theater companies. As mentioned earlier, it not only boycotted, but actively attacked the Magyar Színjátszó Társaság through articles and a publicity blockade. While it had a fluctuating relationship with the Embassy of the People's Republic of Hungary, from the mid-50's and during the 60's, Hatikva and the Embassy followed a common strategy against the exiles of ' 48 .

\footnotetext{
${ }^{14}$ Since 2005, a new periodical serves the community, the Argentínai Magyar Hírlap, published by Susana Kesserü de Haynal. It appears monthly, ten times per year, with separate youth and Spanish language sections. It is today the only Hungarian language publication in Latin America.

${ }^{15}$ Both its publisher and its editor, István Vörösváry and Márton Kerecsendi Kiss, emigrated to Toronto, and from 1957 published Kanadai Magyar Élet (later Kanadai Magyarság), the popular “Kék Újság” still alive today under Béla Aykler.
} 
Némethy, Judith Kesserü. "Exiled Hungarians in Argentina 1948-1968: The Formation of a Community.” AHEA: E-journal of the American Hungarian Educators Association, Volume 5 (2012): http://ahea.net/e-journal/volume-52012

One telling indicator of the cultural effervescence of the Hungarian communities Argentina between 1948 and 1968 is the number of newspapers started by immigrants: 73 publications appeared during that period, 10 of which were published or supported by the People's Republic of Hungary, 1 by the Jewish-Hungarian community (Hatikva), the other 62 by the Exiles of ' 48 . Of these latter, 17 were political or social in tenor, 10 religious, 9 belonged to organizations, another 9 were youth-oriented, and the remaining 17 of varied content.

\section{The Embassy of the People's Republic of Hungary and the Exiles of 1948}

As already mentioned in the introduction, the exiled of ' 48 presented a united front in their strong anti-Bolshevism. Consequently, their relationship with the local embassy of the People's Republic of Hungary was obviously hostile. They opposed each other as representatives from two diametrically opposed cosmic visions, and this determined their association in the decades that followed. The exiled of ' 48 considered themselves to be the depositories of the essence and values of Christian Hungary, despoiled of their rights. The president of the Centro Húngaro formulated his mission in the following terms: "We, the Hungarians who live in the Free World, must continue to fight without truce for the survival of Hungarians. This task includes informing the Western world about the situation of our people and about its role in the Danube Basin; moreover, this entails the duty to work endlessly among ourselves for our national survival." [Nekünk, szabad világban élö magyaroknak változatlanul folytatnunk kell a harcot a magyarság megmaradásáért. S ebben a feladatban benne foglaltatik a nyugati világ felvilágositása a magyarság helyzetéröl és dunamedencei szerepéröl, de benne foglaltatik az is, hogy a magyarság fennmaradásáért magunk között is folytassuk a szüntelen munkálkodást.] (MHÉ 1956/5)

The exiles configured their colonial life, their institutions, and their relationships in this spirit. They isolated themselves totally from the Embassy of the People's Republic of Hungary, which represented for them oppressive Soviet Communism and, for that reason, could not be recognized legitimately. The People's Republic of Hungary, for its part, saw these new immigrants as dangerous and subversive. As soon as they arrived in Argentina the Embassy embarked upon a war against them, taking up as its prime charge their neutralization or, using the Embassy's own terminology, their “decomposition” [bomlasztását].

The enmity between the government and the exiles had already existed prior to the establishment of the Embassy in Argentina of the People's Republic of Hungary. Already on June 6 of 1947, in a letter written by the then Vice-President and later Executive President of the governmental agency World Federation of Hungarians, Tivadar Ács, and addressed to the Hungarian Minister of Foreign Affairs, the feeling was clearly expressed. In discussing the activities of Monsignor Dr. Ferenc Luttor and the numerous groups emigrating to Argentina with his help, he stated: "From the point of view of politics and of state security it is inadmissible that elements disagreeing with Hungarian democracy and pursuing opposite political objectives should encroach existentially upon hundreds of thousands of Hungarians. [Politikai, állambiztonsági szempontból sem megengedhetö, hogy százezres magyar tömegek fölött egzisztenciálisan olyan elemek rendelkezzenek, akik a magyar demokráciával sorsközösséget nem tartanak és ellentétes politikai célokat követnek.] Previously, already on October 28, 1946, the head of the Hungarian Business Office in Sweden, Vilmos Böhm, informed his Ministry 
Némethy, Judith Kesserü. "Exiled Hungarians in Argentina 1948-1968: The Formation of a Community.” AHEA: E-journal of the American Hungarian Educators Association, Volume 5 (2012): http://ahea.net/e-journal/volume-52012

of Foreign Affairs: "I report that I have received on repeated occasions letters from Hungarian residents in Venezuela, Argentina, and Brazil, notifying me that there is a growing current of war criminals, Horthyists, Hungarian Nazis, and Arrow Cross applying for and getting permission to enter South America" [Jelentem, hogy a Venezuelában, Argentínában és Brazíliában élö magyarok ismételten felkeresnek leveleikkel, amelyekben tudomásomra hozzák, hogy háborús gonosztevők, horthysták, magyar nácik és nyilasok mind nagyobb számban áramlanak a dél-amerikai államokfelé, kérnek és kapnak beutazási engedélyt.] (MOL 1946)

It is evident that the Hungarian diplomatic representation in Buenos Aires was prepared to fight the arrival of the new exiles. It had already begun its campaign against them directly and through the Törekvés Club in 1948. The AMZSE joined in the offensive through articles published in their periodical Hatikva, initiating egregious attacks against the Exiles of 1948. All of those who emigrated in 1945 were called "fascists" without any differentiation, despite the fact that there was a good deal of ideological variation among them. ${ }^{16}$ Granted, there were members of the Arrow Cross, the extreme right-wing and anti-Semitic faction, but these represented only a small fraction of the émigrés who arrived in Argentina in 1948. The vast majority of the emigrants were characterized by their anti-Bolshevik stance, but this did not necessarily translate into fascist affiliation nor sympathies.

On November 11, 1948, Magyar Út wrote the following: "More and more, there are signs that pro-Bolsheviks are preparing a great attack against the new immigration in Argentina. Our friends the Croats, Slavs, Poles, Serbs, Romanians, and Czechs all warn us at the same time that mysterious hands are preparing a league. Its objective: to incriminate. It wants to compromise, in full view of the Argentine leaders and the entire nation, those who have fled Bolshevism and recently arrived in Argentina in either small or large groups. And so these words are directed primarily at our Argentine friends... Of the Hungarian immigrants who disembarked on your shores the last 10 to 15 months, with the permission of the Argentine government, 99\% among them have escaped from the Bolsheviks." [Egyre több jel mutatja, hogy bolsevista-barát elemek nagy támadásra készülnek Argentínában az új emigráció ellen. Horvát, szlovák, lengyel, szerb, román, cseh barátaink egyszerre figyelmeztetnek bennünket, hogy titokzatos kezek szövetkezést készitenek elö. Céljuk: vádemelés. Kompromittálni akarják Argentína népe és vezetői elött azokat, akik a bolsevizmus elöl menekülve, kisebb-nagyobb csoportokban most vándoroltak be Argentínába. E sorok tehát elsösorban argentin barátainknak szólnak. .. Azok a magyar bevándorlók, akik az argentin kormány engedélyével az utolsó tíz-tizenöt hónapban itt partra szálltak, kilencvenkilenc százalékban a bolsevizmus elöl menekültek el.]

As a result of these and other Communist actions, the Argentine authorities in 1950 placed the embassies of the Socialist bloc under surveillance. In one report, the business head of the Hungarian ambassador gives an account of some difficulties that the embassy encountered during its espionage activities: "I respectfully communicate that the situation of the Embassy changed dramatically in August. Due to police intervention, we

\footnotetext{
${ }^{16}$ In Hungary, throughout the period of Soviet Occupation, it was customary to apply this collective epithet to the huge mass of people who fled around 1945, although the majority did not understand clearly the real meaning of the term nor its historical antecedents.
} 
Némethy, Judith Kesserü. "Exiled Hungarians in Argentina 1948-1968: The Formation of a Community." AHEA: E-journal of the American Hungarian Educators Association, Volume 5 (2012): http://ahea.net/e-journal/volume-52012

have completely interrupted our "fishing expeditions" (investigations of individuals). In the interest of the security of our friends, we are suspending personal contacts. We have confirmed police control of our branch until August 20." [Tisztelettel jelentem, hogy a Követség helyzete augusztus hónapban erösen megváltozott. A rendöri intézkedések következtében tájékoztatási szolgálatunkat magán személyek felé megszakítottuk. Személyes érintkezéseinket barátaink biztonsága érdekében szüneteltetjük. Követségünk rendöri ellenörzését augusztus 20-ig tapasztaltuk.] (MOL 1950/8/8)

After 1950, the Hungarian Embassy regularly informed the Ministry of Foreign Affairs of the activities of the Hungarian organizations in Argentina. From the content of these reports, one can infer that their main source of information were most likely the émigré newspapers. Still, these reports about the émigrés of 1948 are as incomplete as they are inexact. For example, in reference to the Mindszenty Academy, in a statement dated August of 1952, they declare that "supposedly the conferences already had started" when these systematically had been evolving from the beginning of 1951 and the Délamerikai Magyarság as well as the Magyarok Útja had regularly reported such activity. In reference to the Centro Húngaro, the aforementioned reports state that wine harvest festivals, among other activities, had been celebrated in its facility, when in fact this never occurred. ${ }^{17}$ Even more serious was the Embassy's error when it insinuated that the organizations or their respective directors had received U.S. funds for their work.

From the correspondence between the Ministry of Foreign Affairs and its embassy in Buenos Aires, one can deduce that the Hungarian People's Republic utilized diverse methods in its war against right-leaning refugees, be it propaganda, calumny, or entrapment established on false trust. Among the last of these, there figured on the one hand the offer of amnesty and, on the other, the "initiative to repatriate," which were directed at public personalities. ${ }^{18}$ The most famous "repatriation" was certainly Antal Páger's, who was wooed relentlessly for two years, with the Embassy promising him the return of his villa in Budapest, free decision in the choice of roles, and - of equal importance - the full financial support of his wife and two daughters in Argentina until his situation was stabilized. The first two took years to materialize, and only after he bowed to the Communist regime. His wife, the actress Júlia Komár, was denied all support, and died abandoned and in utter poverty in Argentina in $1976 .{ }^{19}$

From the early 50's, the Embassy tried to lure 1948-ers back to Hungary primarily through the mediation of older, long established emigrant clubs. It began to form relationships with the Hungarian Association of Wilde in 1954, first by sending it books, later by sending propaganda films. Next, the Embassy started setting up contact with clubs that previously avoided any connection with the Communist regime, such as the Hungarian Association of

\footnotetext{
${ }^{17}$ From this we can infer that access to publications about the 1948 exiles was irregular, even non-existent.

${ }^{18}$ Note (from meeting with the ambassador): "Ad. 7. Argentínában és a többi délamerikai államban élö magyarság helyzete, velük való kapcsolat. [...] Az amnesztiarendelet végrehajtását a követség nagyobb propaganda munkával támogassa. Használja fel erre a bulletint, a rádiót, a demokratikus egyesületeket, stb. Propaganda szempontból hozzunk haza Braziliából is 2-3 embert és fizessük utiköltségét 1-2 nem amnesztiarendelettel hazatérö régi emigránsnak is." [Item 7. Situation of the Hungarian residents in Argentina and in other countries of South America, relation with them. [...] The Embassy should aid the execution of the amnesty decree with the greatest amount of propaganda, utilizing pamphlets, the radio, democratic associations, etc. With propaganda aims, let us also bring home 2-3 persons from Brazil, paying their fares, and pay also the fare of 1-2 older immigrants who are returning without the amnesty decree.] (MOL 1951.5.29)

${ }^{19}$ I can personally vouch for the above. My family and the Págers lived on the same floor of a small apartment building in Buenos Aires, and had close contact; my mother was also the Theater Company's prompter- JKN.
} 
Némethy, Judith Kesserü. "Exiled Hungarians in Argentina 1948-1968: The Formation of a Community.” AHEA: E-journal of the American Hungarian Educators Association, Volume 5 (2012): http://ahea.net/e-journal/volume-52012

Avellaneda and the Hungarian Choir of Valentín Alsina. It was an effective way to approach expatriates longing for ties with the faraway mother country. The reports sent by the Hungarian Ministry of Foreign Affairs regularly emphasized that the object of these viewings - aside from forming natural links with the Embassy - was to undermine the unity of the "disloyal" émigrés (that is, those not loyal to the People's Republic of Hungary) and weaken the Centro Húngaro. At first, the campaign faced serious opposition, at Wilde and elsewhere. But in the long run it was successful with those institutions, as seen in the case of the Hungarian Association of Wilde, where, after several years, members broke apart into two factions: one friendly to the Centro Húngaro, the other switching allegiance to the Embassy. Finally, the club fell entirely under the influence of the Embassy. (MOL 1954)

In 1957, the Ministry of Foreign Affairs of the People's Republic of Hungary clearly redacted the official state policy in regards to the exiled Hungarians: "Tasks related to the émigrés in Argentina: Concerning ourselves with them is a point we should not neglect in the foreign policy of the People's Republic of Hungary. Numerous facts indicate that those we cannot conquer for our popular democracy, for our nation, or those we cannot neutralize, fall into the net of imperialist espionage organizations to serve their subversive and propaganda aims, which are used against us in countless cases. [...] The practice of these last years has demonstrated that the decision to reinforce our help to the loyal faction of the émigrés was the correct one. Until last October's counterrevolution, these steadfast organizations demonstrated great success, thanks, in part, to the proper orientation developed by our embassies. After the counterrevolution, a new situation presented itself in this field. Many abandoned the progressive emigrant associations due to the change in their political stance, out of fear, because they saw the true nature of the organization, or as a consequence of a personal decision..." [Emigrációval kapcsolatos feladatok Argentínában. A Magyar Népköztársaság külpolitikájában nem elhanyagolandó szempont az emigrációval való foglalkozás. Számos tény bizonyítja, hogy akiket nem nyerünk meg népi demokráciánk, hazánk számára, vagy legalább nem semlegesítjük, az imperialista kémszervezetek hálójába kerülnek, azok diverzáns és propaganda céljait szolgálják és számtalan esetben felhasználják öket ellenünk. [...] Az elmúlt évek gyakorlata megmutatta, hogy helyes volt a lojális emigrációs szervezetek támogatásának erősitése. A múlt évi októberi ellenforradalomig ezek a lojális szervezetek és egyesületek jelentös sikereket értek el, nem kis részben követségeink helyes irányitó tevékenysége eredményeképpen. Az októberi ellenforradalom után új helyzet állt elö ezen a téren. Sokan politikai álláspontjuk megváltoztatása, igazi arcuk megmutatása, félelem, egyéni meggondolás, stb. következtében kiléptek a haladó emigrációs szervezetekböl. ... ] (MOL 1957/9/12)

After receiving reports from the Embassy on the various Hungarian clubs in Buenos Aires, the official agencies of Hungary became more and more alarmed at the increasing extension of the Centro Húngaro's activities. In an attempt to counter them, the agencies proposed to reinforce the Törekvés cultural program, instructing the Embassy to "taking all possible measures, orient the actions and activities of the Törekvés Association toward the scope of the Hungarian emigrants residing in that country." ("a lehetöségekhez mérten irányitsák a Törekvés Egyesület tevékenységét és munkálkodását az ott élö magyar emigráció körében") The Independent Agency on Hungarians Outside Hungary (Külföldi Magyarok Önálló Referátuma), in its letter to the Embassy dated January 18, 1960, regarding "the effervescence manifested among the Hungarian immigrants residing in Argentina," advised to "significantly activate the Törekvés Association's cultural programs in order to counteract the progressively escalating 
Némethy, Judith Kesserü. "Exiled Hungarians in Argentina 1948-1968: The Formation of a Community." AHEA: E-journal of the American Hungarian Educators Association, Volume 5 (2012): http://ahea.net/e-journal/volume-52012

activity of the right" ( ... "kitünik az Argentínában lévő magyar emigrációban végbemenö forrás és a jobboldal egyre fokozódó tevékenysége. [...] azt bizonyítják, hogy a Törekvés Egyesület aktivizálódásával, kultúr és egyéb programjainak növelésével kellöen ellensúlyozni lehet a jobboldali egyesületek tevékenységét (MOL 1959). However, this effort became moot after reception of the Törekvés secretary's gloomy reply, speaking out about the depletion of the association and the progressive rhythm of assimilation. (MOL 1959).

In 1961, the Commission of the Central Committee of the Hungarian Workers' Socialist Party (MSZMP) gave precise directives for the mission to be accomplished among the Hungarian immigrants: "... Parallel to the activation of the organizational work of the loyal and progressive movement, focus your attention permanently on the reactionary organizations of the Hungarian emigrants and their press. Through promotional visits to Hungary and directed repatriations, increase the personal dissentions within its core and go on reducing ceaselessly their internal influence in the colony through adequate propaganda. ..." [... A haladó és lojális mozgalom szervezeti munkájának aktívabbá tételével párhuzamosan állandóan kisérjék figyelemmel a reakciós magyar emigráns szervezeteket és sajtóikat. Irányított hazalátogatások és hazatelepitések szervezésével növeljék belsö személyi ellentéteiket s megfelelö propagandamunkával állandóan csökkentsék befolyásukat az emigráción belül....](MOL 1951.12.15). From 1964 on, the Embassy launched a more intense and also more effective cultural venture by promoting, first of all, its participation in film festivals and, in addition, by organizing a graphic exposition. Representatives from various organizations, along with important individuals from the community, were being invited to view movies and art shows at the Embassy. These occasions were transformed into social reunions and, little by little, some members of the Centro Húngaro began attending them. ${ }^{20}$

The Embassy's cultural campaign did produce a partial opening toward it, since these visits were separate from the trips people made on official business, such as applying for visas or other official documents, for matters regarding travel to the homeland and permission for relatives to visit them, or to obtain books and popular publications, - yet it also partly achieved the embassy's aim at subverting the émigrés' united front. Nonetheless, neither the Centro Húngaro nor its legal successor the Hungária Association (created in 1973) ever invited representatives of the People's Republic of Hungary to their premises. Gyula Borbándi, in his book Emigració és Magyarország, points out this fact: "During the decades of Hungarian Communism, the Hungarian leaders and organizations in Argentina unanimously rejected all contact with the institutions in Hungary." In the case of the Hungária Association, this attitude persisted until 1990, the year that witnessed the fall of the Iron Curtain.

\footnotetext{
${ }^{20}$ The 1967 August-September edition of Nemzetőr (Munich) says the following: "The Hungarian Embassy imposed a new measure in South America to spiritually disarm the émigrés. They put on Hungarian movies, free of charge. After the showing, they invite the guests to food and drink and, on saying good-bye, they give a bottle of Tokaj wine to the men and folk embroidery to the women. On the last occasion, in Buenos Aires, they also distributed some Communist propaganda booklets written in Spanish, which caught the attention of the Argentine police besides." [Délamerikában új módszert vezetett be a magyar követség az emigráció lelki leszerelésére. Ingyenes belépéssel magyar filmeket mutatnak be. Az elöadás után itallal és étellel kínálják meg a vendégeket, majd búcsúzáskor a férfiak egy üveg tokajit, a nök népi himzéseket kapnak. Legutóbb Buenos Airesben spanyol nyelvü kommunista propagandakönyveket is szétosztottak, amelyre az Argentin rendörség is felfigyelt.]
} 
Némethy, Judith Kesserü. "Exiled Hungarians in Argentina 1948-1968: The Formation of a Community.” AHEA: E-journal of the American Hungarian Educators Association, Volume 5 (2012): http://ahea.net/e-journal/volume-52012

Today, after 60 years and although greatly diminished, the Hungarian community in Argentina is still active and dynamic. The Centro Húngaro and the strong institutions of the beginning built a solid foundation through which assimilation has been delayed. Today, the center of activities is the Centro Húngaro's descendant, the Hungária club. There is also a periodical, a library and archive, an art and music association, a literary group, two amateur theatre groups, a choir, three folklore groups. Both the Catholic center (Mindszentynum) and the Protestant churches are still active. The standard bearers of Hungarian culture in Argentina still today are its youth organizations, namely the Zrínyi Ifjúsági Kör (ZIK) and the scout troops of the Hungarian Scout Association in Exteris. Their leaders (themselves born in Argentina) are educating the third and fourth generation of Hungarian descendants, in some cases grandchildren of the community's founders. They do so through weekly instruction at the weekend school and through the regular scout meetings and camps. But they also achieve this by securing that the youngsters experience their cultural roots studying in Hungary and the Carpathian Basin, or through meeting other diaspora youths in Hungarian scout camps in the United States, Western Europe or Australia. It should be noted that today these efforts would be uncertain were it not by the pro-active support Hungary provides today to its diaspora through scholarships, grants, pedagogy and methodology workshops, as well as cultural or artistic programs. This assistance is invaluable, especially in communities such as the Argentine, which for three generations have maintained their cultural identity on their own strength alone.

In conclusion, strong educational and cultural institutions established by the Exiles of 1948, as well as the community's intense will to survive, have achieved a goal seldom seen in the diasporas: the fact that their descendants -- third and even fourth generation of Hungarian Argentines -- not only are proud of their roots and maintain their cultural values, but feel an integral part of the Hungarian nation as a whole.

\section{Works Cited}

Andera, Víctor. 1955. La población y la inmigración en Hispanoamérica, 106-112.1. Madrid. Borbándi, Gyula, 1989. A Magyar emigráció életrajza 1945-1985. Budapest: Európa . 1996. Emigráció és Magyarország, Nyugati magyarok a változások éveiben 19581995 Basel-Budapest.

Csikós, Zsuzsa. 1988/7. “Magyar szervezetek és újságok Argentínában” (1945-1956), in: Tiszatáj, Szeged.

Dömény, János. 1999. “A magyar emigráció szerepe a magyar-latinamerikai kapcsolatok II. Világháború utáni felújításában.” MTA-JATE Kutatási Közlemények. Tanulmányok a latin-amerikai magyar emigráció történetéröl. p. 69. Szeged: Hispania

Délamerikai Magyarság, 1952, 1955. Buenos Aires. (DM)

Haynalné Kesserü, Zsuzsánna. 2007. “Chacoi Magyarok I-II” in: Argentínai Magyar Hírlap, July-August. Supplement I. Buenos Aires. http://epa.oszk.hu/00600/00674/00024/pdf/00024a.pdf

Kerecsendi Kiss, Márton. 1949 “Az argentinai magyarság kulturális feladatai” in Jó munkát! vol.2. Buenos Aires: Teleki Pál Cserkész-munkaközösség.

Kesserü, István. 1984. “Az argentínai magyar emigráció 1945 után”. Cleveland, OH: A XXIII Magyar Találkozó Krónikája. 
Némethy, Judith Kesserü. “Exiled Hungarians in Argentina 1948-1968: The Formation of a Community.” AHEA: E-journal of the American Hungarian Educators Association, Volume 5 (2012): http://ahea.net/e-journal/volume-52012

Kovács, Nóra. 2009. Szállítható örökség. Magyar identitásteremtés Argentínában (1999-2001). Budapest: Gondolat-MTA Kisebbségkutató Intézet, 240 pp.

Kurucz, Ladislao. 1999. Los húngaros en la Argentina / A magyarok Argentínában. Buenos Aires: Ediciones Biblioteca Nacional. (Bilingual edition), 322 pp.

Magyar Ház Értesítöje. 1956, Buenos Aires. (MHÉ)

Magyarok Utja, 1949, Buenos Aires (MÚ)

Magyar Országos Levéltár. [MOL XIX-J-l-Arg-] 1946-1968.

Némethy Kesserü, Judit. 2003. "Szabadságom lett a börtönöm" Az argentínai magyar emigráció története 1948-1968. ["My freedom became my prison". History of the Hungarian émigrés to Argentina. 1948-1968] Budapest: A Magyar Nyelv és Kultúra Nemzetközi Társasága, 424 pp. (NKJ) . 2010. "The Impact of the 1956 Hungarian Revolution in Argentina". The 1956 Hungarian Revolution: Hungarian \& Canadian Perspectives, Christopher Adam, Tibor Egervari, Leslie Laczko \& Judy Young, eds. Ottawa: University of Ottawa Press, pp. 140-150.

Nemzetör, 1967. Munich

Szabó, László. 1982. Magyar múlt Dél-Amerikában (1519-1900], "Néhány szó a könyv elé" (Tardy László). Budapest: Európa

Új Hungária, 1954, July 30. Munich (ÚH)

Vácz, Elemér [manuscripts]. Hungária Könyvbarátok Köre, HKK, Buenos Aires 